ENTREPRENEURSHIP AND SUSTAINABILITY ISSUES

ISSN 2345-0282 (online) http://jssidoi.org/jesi/

2021 Volume 9 Number 2 (December)

http://doi.org/10.9770/jesi.2021.9.2(18)
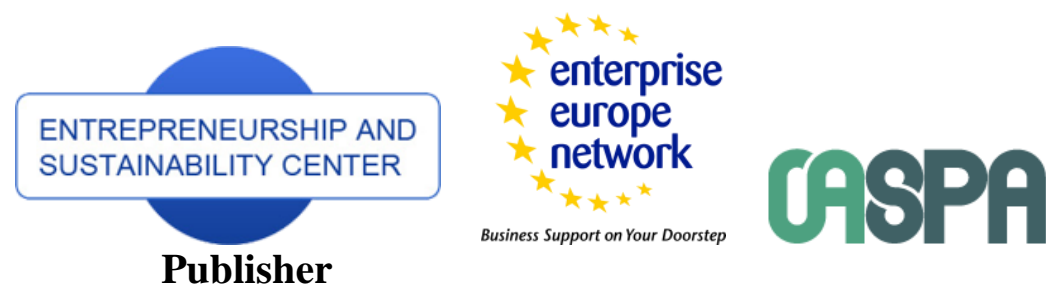

http://jssidoi.org/esc/home

Business Support on Your Doorstep

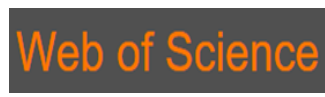

1) Clarivate

Analytics

\title{
HOW TO MAKE CORPORATE SOCIAL DISCLOSURES COMPARABLE?*
}

\author{
Hanna Czaja-Cieszyńska ${ }^{1}$, Dominika Kordela ${ }^{2}$, Beata Zyznarska-Dworczak ${ }^{3}$ \\ ${ }^{1,2}$ Institute of Economics and Finance, University of Szczecin, Mickiewicza 64 Szczecin, Poland \\ ${ }^{3}$ Poznan University of Economics and Business, Niepodległości 10, Poznań, Poland
}

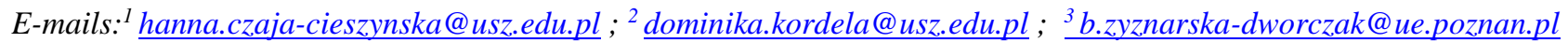

Received 18 August 2021; accepted 5 October 2021; published 30 December 2021

\begin{abstract}
The paper aims to develop instruments supporting the comparability of social disclosures and ipso facto business transparency. This research study aims to assess the possibility of achieving social disclosure comparability based on research of the Polish listed companies and to develop an authorial tools which may support stakeholders in comparing social performance and thus help them make business decisions.To attain the goals, this article introduced practical and theoretical premises of sustainability reporting development in its social dimension. Based on that, an empirical study was conducted on the comparability of social disclosures in sustainability reporting of Polish listed (WIG20) companies. For this purpose, a social disclosure index was developed by the authors. The findings of our study indicate that corporate social disclosures can be the subject of comparisons supporting stakeholders in the decision-making process. The conducted comparability analysis refers to the comparison of the scope of disclosures between the WIG20 companies, as well as the scope of disclosures over three years, and helps us to construct the index as a tool for social disclosure benchmarking. This paper contributes to filling the gap relating the social disclosure comparability. The results of this study may help compare any social disclosures, and the proposed index may be a practical instrument of benchmarking. The research originality refers to the research niche relating to the difficult comparison of non-financial data and the scope of social disclosures in sustainability reporting. It extends the knowledge on this area by giving a new perspective on the comparison of social disclosures.
\end{abstract}

Keywords: comparability; non-financial reporting; responsibility; social disclosures; sustainability; sustainability reporting

Reference to this paper should be made as follows: Czaja-Cieszyńska, H., Kordela, D., Zyznarska-Dworczak, B. 2021. How to make corporate social disclosures comparable? Entrepreneurship and Sustainability Issues, 9(2), 268-288. http://doi.org/10.9770/jesi.2021.9.2(18)

JEL Classifications: M41, M48, Q5

\footnotetext{
*The project is financed within the framework of the program of the Minister of Science and Higher Education under the name "Regional Excellence Initiative" in the years 2019 - 2022; project number 001/RID/2018/19; the amount of financing PLN 10,684,000.00.
} 


\section{ENTREPRENEURSHIP AND SUSTAINABILITY ISSUES}

ISSN 2345-0282 (online) http://jssidoi.org/jesi/

2021 Volume 9 Number 2 (December)

http://doi.org/10.9770/jesi.2021.9.2(18)

\section{Introduction}

A rising trend for corporate social disclosures in sustainability reporting may be viewed as a response to the growing needs of stakeholders and legislative changes introduced by governments in that respect. It may tend to raise the consciousness of a historical lack of concern for it and to promote social aims in the corporate context. Thus, the amalgamation of disclosure requirements with social goals tends to signal a convergence of private and public goals in the corporate sphere (Choudhury, 2016). Moreover, this trend is also due to two other factors reducing the information asymmetry between stakeholders and organizations, as well as improving corporate accountability. The transparency provided by social disclosures may also encourage stakeholders to engage in these issues. The research results so far indicate that social disclosures are expected by stakeholders to be credible and comparable (Widiarto Sutantoputra, 2009; Fifka, 2013; de Souza Gonçalves et al., 2014; Martínez-Ferrero et al., 2016).

The essence of social disclosures limits the possibilities of assessing and comparing the results (both against the industry and the individual's progress over time), as they serve to reveal such difficult-to-measure categories as, for example, labor/management relations, occupational health and safety, training and education, diversity and equal opportunity, non-discrimination, freedom of association and collective bargaining, rights of indigenous peoples, human rights assessment, local communities, supplier social assessment, customer health and safety, socioeconomic compliance. Their assessment by stakeholders interested in sustainable development may be of key importance in their decisions, hence the need to build instruments supporting the assessment of disclosures in this area.

The scope of reporting on the social aspects of sustainable development varies between countries, as well as between industries and individual entities. Social issues may be presented in a variety of ways - as descriptive and numerical information disclosed obligatorily or optionally, presented according to various national or international standards, as a separate statement or as part of annual reports. Additionally, the different scope of disclosures, including social disclosures, is also influenced by environmental, cultural, social, ethical, and historical factors (Van der Laan Smith et al., 2005; Orij, 2010; Ali et al., 2017; Zyznarska-Dworczak, 2018a), which additionally makes it difficult to compare social disclosure. Moreover, social disclosure obligations mainly focus on narrative information, meaning that the information is more difficult to standardize and does not easily enable comparisons or benchmarking (Choudhury, 2016). Thus, the dominant non-financial nature of social disclosures hinders their estimation by stakeholders based on sustainability reporting and thus may adversely affect their decision-making. So, it is necessary to develop instruments supporting the comparability of these results, and ipso facto business transparency.

Therefore, the main goal of the study was to contribute to understanding of the growing importance of corporate social disclosure in sustainability reporting. This research study aimed to assess the possibility of achieving social disclosure comparability based on the research of Polish listed companies (included in the WIG20 index) and to develop an original authorial tools, which may support stakeholders in comparing social performance and thus help them make business decisions. To attain the goals, this article introduced practical and theoretical premises of sustainability reporting development in its social dimension. Based on that, an empirical study was conducted on the comparability of social disclosures in sustainability reporting of Polish listed (WIG20) companies. As a result, a rating of the listed companies and a social disclosure index were developed by the authors. This study applied the following research methods: literature review, content analysis, desk research, Delphi method, tools of descriptive statistics, the method of induction, and synthesis.

The findings of our study indicated that corporate social disclosures can be the subject of comparisons supporting stakeholders in the decision-making process. The conducted comparability analysis referred to the comparison of 


\section{ENTREPRENEURSHIP AND SUSTAINABILITY ISSUES}

ISSN 2345-0282 (online) http://jssidoi.org/jesi/ 2021 Volume 9 Number 2 (December)

http://doi.org/10.9770/jesi.2021.9.2(18)

the scope of disclosures between the Polish-listed companies (WIG20), as well as the scope of disclosures over three years, and helped us to construct the index as a benchmarking tool for the social disclosure. This instrument may support the stakeholders by indicating whether the scope of data disclosed by a given company is higher or lower than the index average. Moreover, this index and its structure allow being used also to evaluate the other two disclosure areas of corporate sustainability: governance and environment. Furthermore, since there are only few studies that examine the importance of social disclosures in sustainability reporting, little is known about the comparability of social disclosures presented in sustainability reports. This paper contributes to filling this gap. The results of this study may help in the comparison of social disclosure, and the proposed index may be a practical instrument of benchmarking.

This study provides new insights into the niche relating to the difficult comparison of non-financial data and the scope of social disclosures in sustainability reporting, thus contributing to the literature in this research area and supporting data reliability and transparency in practice. It relates to the proposal of the authorial index, which enables benchmarking and comparing the corporate results in the social area of corporate sustainability. It extends the knowledge on the practices concerning sustainability reporting in this area by giving a new perspective on the comparison of social disclosures, a topic that has not yet been investigated in-depth.

This article proceeds in six parts. The next section provides the research background explaining the trend in social disclosure research and justifies the conducted study. It offers a review of the relevant literature, defines the research gap and develops the research hypotheses. The third section of the paper presents empirical research. It describes the sample and variables, the methodology, and the research model that is applied in data analysis and hypothesis verification. Furthermore, it provides the assessment and the segmentation of disclosure standards based on the Delphi method, the proposal of a rating of social disclosure comparability, as well as the authorial index formula. The fourth part presents the results, and the fifth one discusses them. The last part of the paper outlines the conclusions of the research paper.

\section{Practical and theoretical underpinning, literature review and hypotheses development}

Nowadays, sustainability reporting is developing so intensely and in so many directions that it raises many problems in ensuring the comparability of the data disclosed in it. Enterprises' involvement in disclosure of information may be interpreted both from the perspective of legislative premises and scientific and theoretical justification.

Sustainability reporting is currently developing significantly and the changes observed in the practice of enterprises can be interpreted both from the perspective of legislative premises and scientific justification. Across the world, there are many various organizations, initiatives and regulations whose aim is to help to achieve the worldwide convergence and harmonization of sustainability reporting standards. Currently, GRI (Global Reporting Initiative) Standards are considered to be the most common harmonized and flexible reporting model (Skouloudis et al., 2010; Boiral, 2013). Since 2000, a total of over 38.5 thousand non-financial reports have been published as per the GRI regulations all over the world, which accounts for more than $60 \%$ of all such reports (SDD). Pursuant to the regulations, social disclosures should include minimum 19 disclosure categories comprising as many as 76 diverse, non-financial metrics (GRI Standards, 2016). Moreover, in the European context, since 2014 corporate social disclosures have been obligatory for major listed companies. It was the year when the European Directive 2014/95/EU regarding the disclosure of non-financial and diversity information enforced a radical shift from voluntary to mandatory disclosure of non-financial information (Doni et al., 2019).

The legal basis in this respect may be the national, EU or international regulations, as a result of which the scope of non-financial information disclosed by enterprises is diverse, and reports as such are hardly comparable in terms of both time and space. For example, in Poland corporate social disclosures have been obligatory for major 


\section{ENTREPRENEURSHIP AND SUSTAINABILITY ISSUES}

ISSN 2345-0282 (online) http://jssidoi.org/jesi/ 2021 Volume 9 Number 2 (December) http://doi.org/10.9770/jesi.2021.9.2(18)

listed companies since 2017 [1], however, according to some empirical research (Szadziewska et al., 2018; CzajaCieszyńska and Kochański, 2019; Krasodomska and Zarzecka, 2020; Krasodomska et al., 2020) the form of the disclosures still varies, and the scope of the information presented is diverse, especially across various industries. The usefulness of Directive 2014/95/EU in its current form was questioned in many research studies (e.g. Biondi et al., 2020; De Luca, 2020) - on the one hand, it is a key legislative act that represents an important step towards standardization of sustainability reporting and formalizing the transparency requirements, but on the other hand, it still does not ensure comparability of sustainability disclosures revealed by companies (Venturelli et al., 2017; Doni et al., 2020; Krasodomska and Zarzycka, 2020; Czaja-Cieszyńska, 2018).

The existing research studies regarding social disclosure in sustainability reporting are a response to a change in the economic reality. Striving to ensure the highest quality of information disclosed by enterprises is usually justified in the literature from the perspective of three mainstream theories, namely legitimacy theory, stakeholder theory and institutional theory (Chen and Roberts, 2010; Fernando and Lawrence, 2014; Fernando and Lawrence, 2014; Kaur and Lodhia, 2018). Thus, they may explain why organizations make or should make certain social disclosures within their annual reports or within other corporate reports regardless of the regulations.

Proponents of the stakeholder theory (e.g. Freeman and Reed, 1983; Donaldson and Preston, 1995) argue that stakeholder support is critical for the survival of an organization (Kamal, 2021). Therefore, corporate decisions relating to social disclosures should be primarily focused on the information needs of stakeholders (Krasodomska and Zarzycka, 2020). Based on this approach, organizations may enhance stakeholder relations by making social disclosures (Farneti et al., 2019) and thus maintain its 'license to operate' in the society by complying with the expectations of the community according to the theory of legitimacy (see more in: Patten, 1991; O'Dwyer, 2001; Deegan, 2002; Ali, Lodhia and Narayan, 2020). The legitimacy theory is also used to identify disclosure strategies pursued by firms in reaction to the new regulation (Di Tullio et al., 2019). It treats corporate social disclosure as a way to fulfill the organization's social contract focused on winning social acceptance, and retaining it to justify the legality of its corporate activity (Zyznarska-Dworczak, 2018b).

Furthermore, the institutional theory emphasizes that incorporation of institutionalized norms and rules may help to gain stability and enhance survival prospects. This theory views the pattern of the established institutions as the symbolic representation of the social value system (Chen and Roberts, 2010). Based on this approach, social disclosure is determined by several institutional conditions: public and private regulations, institutionalized norms regarding appropriate corporate behavior, associative behavior among corporations themselves, and organized dialogues among corporations and their stakeholders (Campbell, 2007). Moreover, in the perspective of the institutional theory, social disclosure may be treated as an answer of an entity because such reporting practice is commonly implemented by other similar organizations as part of normal business. Nevertheless, such institutional pressures may differ among geographical regions or industries and have a different effect on the behavior of a company (Pedersen et al., 2013).

From the perspective of these three theories, social disclosure may be treated as a manifesto of a company's accountability and its own social value system, based on the institutionalized approach of sustainable development dedicated to stakeholders' expectations as well as to the social contract with the company's environment. However, its reliability is determined by the possibility of comparing the achievements reported by the company against the background of other entities.

For a synthetic and structured analysis of the research area literature, the bibliometric method was applied, based on the Web of Science (WoS). To identify trends in the analyzed area, the bibliometric test included the research studies having in their thematic scope: sustainability, disclosure, social, and comparability. In this way, a database was created, containing 328 publications, covering research articles, conference papers, and review papers relating to social disclosures. The first part of the bibliometric study was based on two different sets of 


\section{ENTREPRENEURSHIP AND SUSTAINABILITY ISSUES}

ISSN 2345-0282 (online) http://jssidoi.org/jesi/ 2021 Volume 9 Number 2 (December)

http://doi.org/10.9770/jesi.2021.9.2(18)

bibliometric data from 1945-2020: the number of publications and its geographical origin (Tables 1-2), whereas the second part of the bibliometric study was related to citations and citation statistics.

The number of publications relating to social disclosures has increased significantly in the last four years, which accounts for over $60 \%$ of all publications in the analyzed scope (Table 1 ).

Table 1. Social disclosure research in the context of comparability in 1945-2020

\begin{tabular}{l|l|l|l|l|l|} 
& Total & Until 2008 & $\mathbf{2 0 0 9 - 2 0 1 2}$ & $\mathbf{2 0 1 3}-\mathbf{2 0 1 6}$ & $\mathbf{2 0 1 7 - 2 0 2 0}$ \\
\hline$\%$ of 328 & $100 \%$ & $1.22 \%$ & $10.37 \%$ & $26.22 \%$ & $61.89 \%$ \\
\hline number of publications & 328 & 4 & 34 & 86 & 203 \\
\hline \multicolumn{6}{r}{ Source: Own elaboration based on Web of Science of April 1, 2021.}
\end{tabular}

Although the science interest in disclosures related to social issues has been steadily growing for the past two decades, it can be concluded that the breakthrough in the dynamics of the growing number of research studies in this area came after 2016. Assuming that European countries lead the way in social disclosure requirements (Choudhury, 2016), this metamorphosis may be seen as an effect of the European Directive 2014/95/EU regarding the disclosure of non-financial and diversity information. Its transposition deadline for the $28 \mathrm{EU}$ Member States into their national legislation was fixed on 6 December 2016, nevertheless, the scope of transposition differed from country to country, resulting in different amounts of information having to be disclosed. Market participants in Western European countries have significantly different perspectives on the importance of corporate responsibilities than those in Central and East European countries (Fijałkowska et al., 2018). Moreover, the different scope of disclosures, including social disclosures, and thus the research interest in this area, is also influenced by some factors relating to environmental, cultural, social, ethical, and historical aspects (Van der Laan Smith et al., 2005; Orij, 2010; Ali et al., 2017; Zyznarska-Dworczak, 2018a, 2020).

Thus, different interests in corporate social disclosures may also be seen from the perspective of geographical origin of the research (Table 2).

Table 2. Social disclosures research by countries in 1945-2020

\begin{tabular}{|l|l|l|}
\hline Countries/regions & Record Count & \% of 328 \\
\hline Spain & 46 & 14.4 \\
\hline USA & 46 & 14.4 \\
\hline Italy & 34 & 10.7 \\
\hline Australia & 29 & 9.1 \\
\hline England & 29 & 9.1 \\
\hline Germany & 22 & 6.9 \\
\hline China & 20 & 6.3 \\
\hline Brazil & 17 & 5.3 \\
\hline Malaysia & 15 & 4.7 \\
\hline India & 12 & 3.8 \\
\hline Portugal & 11 & 3.5 \\
\hline France & 10 & 3.1 \\
\hline New Zealand & 9 & 2.8 \\
\hline Canada & 8 & 2.5 \\
\hline Poland & 8 & 2.5 \\
\hline
\end{tabular}

Source: Own elaboration based on Web of Science of April 1, 2021.

As Table 2 shows, the countries like Spain, USA, Italy, and Australia are distinguished by the highest number of studies on social disclosures, taking into account the context of their comparability. Taking into account the Polish perspective as the research subject of this paper, Poland shows a low level of scientific interest in social disclosures (with $2.5 \%$ of the local database). Hence, the authors found that scientific area to be a niche. 


\section{ENTREPRENEURSHIP AND SUSTAINABILITY ISSUES}

ISSN 2345-0282 (online) http://jssidoi.org/jesi/

2021 Volume 9 Number 2 (December)

http://doi.org/10.9770/jesi.2021.9.2(18)

The second part of the bibliometric test indicated citations to source items indexed within Web of Science Core Collection in 1998-2020 (social disclosure research was not published in the years 1945-1998). The citation statistics are presented in Table 3.

Table 3. The citation statistics of social disclosures research in 1998-2020

\begin{tabular}{|l|l|}
\hline Citation Statistics & \\
\hline Results found & 328 \\
\hline Sum of the Times Cited & 5400 \\
\hline Average Citations per Year & 36.73 \\
\hline Average Citations per Item & 16,93 \\
\hline h-index & 37 \\
\hline
\end{tabular}

Source: Own elaboration based on Web of Science of April 1, 2021.

Considering the short period of scientific interest in social disclosure, there is a relatively high response in the citations. However, based on the comparison of the cumulative citation results over the last 20 years, over $90 \%$ of them come from 2014-2020. Moreover, the conducted citation analysis allowed identifying the most popular research results - Eccles et al. (2014), Fifka (2013), Michelon et al. (2015), Mahoney et al. (2013) and GarcíaSánchez et al. (2013). Eccles et al. (2014) have observed that during the last twenty years a relatively small but growing number of companies have begun to voluntarily integrate social and environmental issues in their business models, organizational processes, and their strategy through the adoption of related corporate policies. Based on that, the researchers explored the organizational and performance implications for such organizations. They compared 180 US companies, 90 of which classified as High Sustainability companies, while another 90 as Low Sustainability companies with the traditional model of corporate profit maximization in which social and environmental issues are typically regarded as externalities. The analysis conducted over the 18-year research period showed that the High Sustainability companies significantly outperformed their counterparts over the longterm, both in terms of the stock market and accounting performance, as well as that the market underestimated the future profitability of the High Sustainability companies compared to the Low Sustainability ones.

Such conclusions are consistent with the research results published in Michelon et al. (2015). The researchers investigated the quality of disclosure along three dimensions: the content and the type of information, as well as the managerial orientation. They found that the use of social responsibility practices was not associated with higher disclosure quality, suggesting that these practices were symbolic rather than substantive. The authors stated that such results may be a basis for increasing skepticism about the use of CSR reporting practices as tools used to enhance perceived accountability. Nevertheless, the authors proved that disclosures by GRI followers were more likely to be balanced, comparable, and precise.

The presented conclusions complement the research results obtained by Mahoney et al. (2013). The authors researched firms' motivations for social responsibility disclosure, found that firms that voluntarily issued standalone social reports generally had higher social performance scores. They stated that firms were using voluntary social reports to publicize stronger social and environmental records to stakeholders. Other factors of social disclosure are highlighted by Fifka (2013) and García-Sánchez et al. (2013). Fifka (2013), based on a meta-analysis of 186 studies, examined the determinants of social responsibility disclosure research. He proved that the general political and socio-economic environment had a very strong impact on reporting practices and the country-related factors showed a very strong correlation with reporting. García-Sánchez et al. (2013), in turn, examined the impact of the Hofstede national cultural system on integrated reporting to prove that companies located in societies with stronger collectivist and feminist values were in the vanguard of information integration.

The analyzed publications, chosen based on the bibliometric test, show the main research problems concerning social responsibility disclosure i.e. different levels of firms' motivations, engagement, regulations, reporting standards, political and socio-economic factors. Social disclosure equally is affected by these difficulties relating to reliability, credibility, and comparability between entities, industries, and even between countries. So ensuring 


\section{ENTREPRENEURSHIP AND SUSTAINABILITY ISSUES}

ISSN 2345-0282 (online) http://jssidoi.org/jesi/

2021 Volume 9 Number 2 (December)

http://doi.org/10.9770/jesi.2021.9.2(18)

comparability is one of the ways of providing transparency and reliability of disclosed data, both financial and non-financial. Given the above, hypotheses 1 (H1) can be formulated as follows:

\section{H1. Corporate social disclosures provides little basis for comparability of social performance.}

One way of the scientific approach to this research problem is to perform a qualitative analysis of non-financial reports and to create a social disclosure rating system for assessing firms' sustainability reports (Widiarto Sutantoputra, 2009; Orij, 2010). Nevertheless, the exciting research studies (e.g. Skouloudis et al., 2010; de Abreu et al., 2012; de Souza Gonçalves et al., 2014; Singhania and Gandhi, 2015) were dedicated to individual entities operating under national conditions (accordingly Greece, China, Brazil, India). Such an index very often combines all dimensions of sustainability, not only allowing social disclosure to be assessed. So our proposal is dedicated to corporate social disclosures, filling the gap in the existing several international ratings dedicated CSR/ESG disclosure (so combined social and environmental disclosure).

Moreover, taking into consideration the above mentioned differentiations among countries, and stakeholders' demand for reliable non-financial information, the authors of this paper took as the subject of the comparability of social disclosures in Poland. As table 2 shows, there is little research in the analyzed scope dedicated to Polish entities. Available studies (f.e. Czaja-Cieszyńska, Kochański, 2019; Fijałkowska et al. 2018; Hąbek, Wolniak, 2016; Krasodomska, 2015; Krasodomska, Zarzycka, 2020; Wirth, et al. 2016) indicate that corporate social disclosures of Polish companies are difficult to measure and to compare, and the quality level of the disclosures is generally low. So our research is due to support the following hypothesis (H2):

H2. Difficulties in assessing social disclosures imply the need to select quantitative measures to ensure comparability and thus help stakeholders compare social performance.

Thus, in view of the presented research niche in Poland (see Table 2), the following part of the empirical research is dedicated to Polish public companies, their social disclosure, and the social disclosure index.

\section{Study design}

In view of the role and significance of corporate social disclosures for development of non-financial reporting in Poland, the research process was divided into three stages. The first stage of the empirical study was the analysis of the advancement level of non-financial reporting in the individual companies included in the WIG20 index. Completion of the research task required taking two actions. Firstly, it was necessary to define the non-financial metrics of key importance for stakeholders with regard to social disclosures in sustainability reporting. To that end, the Delphi method was applied. Secondly, it was followed by a thorough analysis of secondary data in the form of non-financial reports adopted for the study, using the desk research method.

Delphi method is an expert method, being one of the heuristic methods. It is applied in making decisions based on experts' knowledge, experience and opinions. The primary research technique applied here was surveying. The survey questionnaire was developed in the Microsoft Forms application and comprised two parts: demographics and content-related questions. The content-related part of the survey consisted of 76 questions presenting 76 nonfinancial metrics in 19 disclosure categories in the social area, recommended by the GRI Standards. The experts, using the 3-point Likert scale, were asked to assess the significance of the indicated non-financial metrics from the point of view of companies' stakeholders. The survey involved a group of 15 non-financial reporting specialists including auditors (4), chief accountants (5), academics and business people (6). The respondents were selected on a targeted basis. The survey was conducted in the period from 01.12.2020 to 31.12.2020. It should be noted that the proper survey was preceded by a survey pilot (a pilot test). The survey pilot involved three experts and was aimed at improving the prepared survey questionnaire and making sure the research tool had been 
properly constructed. Only the modified survey questionnaires (i.e. improved to include the suggestions of the survey pilot group) were sent to the other experts (on-line survey). Based on the obtained expert opinions, the non-financial metrics that characterized social disclosures were divided into three groups: hardly significant, moderately significant, and very significant metrics. The classification of the non-financial metrics that characterize the social aspects of non-financial reporting, showing their level of significance, is presented in Table 4 .

Table 4. Assessment of social disclosures metrics

\begin{tabular}{|c|c|c|c|c|c|}
\hline \multirow[t]{2}{*}{ Number } & \multirow[t]{2}{*}{ Disclosure category } & \multicolumn{3}{|c|}{ Classification of non-financial metrics } & \multirow[t]{2}{*}{ Tota } \\
\hline & & $\begin{array}{l}\text { Hardly } \\
\text { significant } \\
\text { metrics }\end{array}$ & $\begin{array}{l}\text { Moderately } \\
\text { significant } \\
\text { metrics }\end{array}$ & $\begin{array}{l}\text { Very significant } \\
\text { metrics }\end{array}$ & \\
\hline GRI 401 & Employment & 6 & 2 & 0 & 8 \\
\hline GRI 402 & Labor/management relations & 0 & 2 & 0 & 2 \\
\hline GRI 403 & Occupational health and safety & 7 & 12 & 3 & 22 \\
\hline GRI 404 & Training and education & 0 & 4 & 1 & 5 \\
\hline GRI 405 & Diversity and equal opportunity & 0 & 4 & 1 & 5 \\
\hline GRI 406 & Non-discrimination & 0 & 0 & 2 & 2 \\
\hline GRI 407 & $\begin{array}{l}\text { Freedom of association and } \\
\text { collective bargaining }\end{array}$ & 2 & 0 & 0 & 2 \\
\hline GRI 408 & Child Labor & 1 & 2 & 0 & 3 \\
\hline GRI 409 & Forced or compulsory labor & 0 & 2 & 0 & 2 \\
\hline GRI 410 & Security practices & 1 & 1 & 0 & 2 \\
\hline GRI 411 & Rights of indigenous peoples & 2 & 0 & 0 & 2 \\
\hline GRI 412 & Human rights assessment & 0 & 3 & 0 & 3 \\
\hline GRI 413 & Local communities & 0 & 2 & 0 & 2 \\
\hline GRI 414 & Supplier social assessment & 1 & 4 & 0 & 5 \\
\hline GRI 415 & Public Policy & 0 & 2 & 0 & 2 \\
\hline GRI 416 & Customer health and safety & 0 & 0 & 2 & 2 \\
\hline GRI 417 & Marketing and labeling, & 0 & 4 & 0 & 4 \\
\hline GRI 418 & Customer privacy, & 0 & 0 & 2 & 2 \\
\hline GRI 419 & Socioeconomic compliance & 0 & 0 & 1 & 1 \\
\hline \multicolumn{2}{|l|}{ Total: } & 20 & 44 & 12 & 76 \\
\hline
\end{tabular}

The experts' indications regarding the significance of the individual non-financial metrics were the starting point for the subsequent stage of the empirical study, i.e. the analysis of secondary data in the form of non-financial reports adopted for the study, using the desk research method. This part of the research process consisted in evaluation of the scope of disclosures made by the companies included in the WIG20 index. The research sample was made up from the companies listed at the Warsaw Stock Exchange and included in the WIG20 index (as at the end of December of each year covered by the study). The sample was selected on a targeted basis, as the WIG20 index covers 20 biggest companies in terms of capitalization and turnover value [2]. The companies represent various sectors of the economy (Table 2). The WIG20 index is dominated by banks, but there are also companies from more capital-consuming sectors characterized by higher values of tangible fixed assets, e.g. fuels or power engineering, as well as new technologies such as telecommunications and gaming sectors. The time scope of the study covers the non-financial reports for 3 full reporting periods, i.e. for the years 2017-2019, when it became obligatory for the biggest Polish public interest entities to report extended non-financial information. The list of Polish-listed companies covered by the study is presented in Table 5. 
ENTREPRENEURSHIP AND SUSTAINABILITY ISSUES

ISSN 2345-0282 (online) http://jssidoi.org/jesi/ 2021 Volume 9 Number 2 (December) http://doi.org/10.9770/jesi.2021.9.2(18)

Table 5. WIG20 companies

\begin{tabular}{|c|c|c|c|c|c|c|c|c|}
\hline \multicolumn{9}{|c|}{ WIG20 as at: } \\
\hline \multicolumn{3}{|c|}{ 31.12.2017 } & \multicolumn{3}{|c|}{ 31.12.2018 } & \multicolumn{3}{|c|}{ 31.12.2019 } \\
\hline $\begin{array}{l}\text { Comp } \\
\text { any } \\
\text { ticker }\end{array}$ & $\begin{array}{l}\text { Weight } \\
\text { in index } \\
(\%)\end{array}$ & Sector & $\begin{array}{l}\text { Comp } \\
\text { any } \\
\text { ticker }\end{array}$ & $\begin{array}{l}\text { Weight } \\
\text { in index } \\
\%\end{array}$ & Sector & $\begin{array}{l}\text { Comp } \\
\text { any } \\
\text { ticker }\end{array}$ & $\begin{array}{l}\text { Weight } \\
\text { in index }\end{array}$ & Sector \\
\hline PKN & 15 & Fuels & PKN & 14.43 & Fuels & PKN & 13.23 & Fuels \\
\hline PKO & 15 & Banks & PKO & 15 & Banks & PKO & 15 & Banks \\
\hline PEO & 9.06 & Banks & PEO & 8.16 & Banks & PEO & 8.12 & Banks \\
\hline PZU & 11.97 & Insurance & PZU & 11.47 & Insurance & PZU & 10.48 & Insurance \\
\hline $\mathrm{KGH}$ & 7.02 & Mining & $\begin{array}{l}\text { KGH } \\
\mathrm{M}\end{array}$ & 6 & Mining & $\mathrm{KGH}$ & 5.99 & Mining \\
\hline SPL & 5.39 & Banks & SPL & 5.92 & Banks & SPL & 4.76 & Banks \\
\hline PGE & 4.39 & Energy & PGE & 4.65 & Energy & PGE & 3.3 & Energy \\
\hline PGN & 4.55 & Fuels & PGN & 4.98 & Fuels & PGN & 3.67 & Fuels \\
\hline LPP & 4.84 & Clothing & LPP & 5.09 & Clothing & LPP & 5.54 & Clothing \\
\hline CPS & 2.44 & $\begin{array}{l}\text { Telecommunic } \\
\text { ations }\end{array}$ & CPS & 3 & $\begin{array}{l}\text { Telecommunic } \\
\text { ations }\end{array}$ & CPS & 3.83 & $\begin{array}{l}\text { Telecommunic } \\
\text { ations }\end{array}$ \\
\hline $\mathrm{CCC}$ & 3.37 & Clothing & $\mathrm{CCC}$ & 2.57 & Clothing & $\mathrm{CCC}$ & 1.53 & Clothing \\
\hline MBK & 2.75 & Banks & MBK & 2.55 & Banks & MBK & 2.46 & Banks \\
\hline ALR & 2.88 & Banks & ALR & 2.24 & Banks & ALR & 1.31 & Banks \\
\hline OPL & 1.62 & $\begin{array}{l}\text { Telecommunic } \\
\text { ations }\end{array}$ & OPL & 1.55 & $\begin{array}{l}\text { Telecommunic } \\
\text { ations }\end{array}$ & OPL & 2.08 & $\begin{array}{l}\text { Telecommunic } \\
\text { ations }\end{array}$ \\
\hline LTS & 2.47 & Fuels & LTS & 3.24 & Fuels & LTS & 3.67 & Fuels \\
\hline TPE & 1.48 & Energy & TPE & 1.11 & Energy & TPE & 0.89 & Energy \\
\hline JSW & 2.2 & Mining & JSW & 1.87 & Mining & JSW & 0.53 & Mining \\
\hline EUR & 1 & Groceries & EUR & 0.65 & Groceries & PLY & 1.77 & $\begin{array}{l}\text { Telecommunic } \\
\text { ations }\end{array}$ \\
\hline $\mathrm{ACP}$ & 1.48 & IT & CDR & 4.62 & Gaming & CDR & 8.71 & Gaming \\
\hline ENG & 1.09 & Energy & ENG & 0.91 & Energy & DNP & 3.12 & Groceries \\
\hline
\end{tabular}

Source: own study based on the Stock Exchange data. List as at the end of December of each year covered by the study.

When the research material had been gathered, a preliminary analysis was conducted for the total of 60 nonfinancial reports adopted for the study. For 57 of them, the basic legal framework was the GRI Standards, which confirmed the domination of these regulations in Poland, and at the same time legitimized selecting them for the research process by the authors. As already said above, pursuant to the GRI Standards, social disclosures comprise 19 categories. Within those categories the total of 76 non-financial metrics were defined. In the analysis of their disclosures, a dichotomous scale of either " 0 " or " 1 " was adopted, where 1 confirms disclosure (the given non-financial metric was provided in the report), and 0 means the metric was not disclosed. Further on, the evaluation of the advancement level in sustainability reporting was extended to include the significance level for the individual metrics, specified by the experts. Upon dividing the metrics into three groups, each of them was assigned a multiplier. For hardly significant metrics the multiplier was "1", for moderately significant ones "1.5", whereas for very significant metrics - "2". As a result, the maximum score obtainable in any given year by each of the analyzed companies was 110 . Table 6 presents the metrics valuation procedure adopted in the research process. 
ENTREPRENEURSHIP AND SUSTAINABILITY ISSUES

ISSN 2345-0282 (online) http://jssidoi.org/jesi/ 2021 Volume 9 Number 2 (December) http://doi.org/10.9770/jesi.2021.9.2(18)

Table 6. Metrics valuation

\begin{tabular}{|l|l|l|l|l|l|}
\hline s/n & Description & \multicolumn{2}{|l|}{ Classification of non-financial metrics } & \multicolumn{1}{l|}{ Total } \\
\cline { 3 - 6 } & & $\begin{array}{l}\text { Hardly significant } \\
\text { metrics } \\
\text { significant metrics }\end{array}$ & $\begin{array}{l}\text { Very } \\
\text { metrics }\end{array}$ \\
\hline 1. & $\begin{array}{l}\text { Number of non-financial metrics of social } \\
\text { disclosures }\end{array}$ & 20 & 44 & 12 & 76 \\
\hline 2. & Multiplier & 1 & 1.5 & 2 & \\
\hline 3. & $\begin{array}{l}\text { Max. score obtainable in the given metrics } \\
\text { group }\end{array}$ & 20 & 66 & 24 & 110 \\
\hline
\end{tabular}

Source: own work.

Based on the total score obtained by a given company in a given year, the advancement level of individual companies in social disclosures was assessed. The disclosure rating was specified based on a 5-grade scale from $\mathrm{A}+$ to $\mathrm{E}$, where A+ means the most advanced level, and E - very low. Such a rating enables comparability of corporate social disclosures. Reference values for the individual categories are presented in Table 7.

Table 7. Assessment social disclosures

\begin{tabular}{|c|l|l|}
\hline $\begin{array}{l}\text { The total score calculated } \\
\text { for a report of a given company } \\
- \text { reference values }\end{array}$ & Advancement level & $\begin{array}{l}\text { Rating of a } \\
\text { given } \\
\text { company }\end{array}$ \\
\hline $88-110$ & Very high & $\begin{array}{l}\text { A+ } \\
\text { A }\end{array}$ \\
\hline $77-87$ & High & $\begin{array}{l}\text { B } \\
\text { B }\end{array}$ \\
\hline $61-76$ & Medium & $\mathrm{C}$ \\
\hline $28-43$ & Low & D \\
\hline $17-27$ & Very low & $\mathrm{E}$ \\
\hline $0-16$ & \\
\hline
\end{tabular}

The last (third) stage of the research process was aimed at developing the authorial index of social disclosure in sustainability reporting and the aggregate evaluation of all the analyzed non-financial reports as at the end of December of each year covered by the study. The index provides information about the aggregated corporate social disclosures of the WIG20 companies, thus enabling comparability of corporate social disclosures. Based on an assumption that the index structure should be simple and understandable, but also comparable over time, the devised index took the following form:

$N F R_{S} I N D E X=\sum_{i=1}^{20} n_{i} w_{i}$

where:

NFRs INDEX - index of social disclosure in sustainability reporting

$n i$ - the score of the ith company, obtained in the individual assessment of the non-financial report for the given year

wi- weight of the ith company in the WIG20 index

he devised index is a tool for comparing over time the advancement level of social disclosures in non-financial reporting for all the companies included in the WIG20 index. The index product consists of factors updated on an annual basis, i.e. the total score obtained by the company for the report $\left(n_{i}\right)$ and the weight of the ith company in the WIG20 index $\left(w_{i}\right)$. Its value may range from 0 to 110 . The higher the index value, the higher the scope of corporate social disclosure. The NFR_S index does not reflect the market valuation of companies, the way it is the case for the WIG-ESG index [3] - as it mainly serves the information purposes (Stock Exchange). Eligibility for 


\section{ENTREPRENEURSHIP AND SUSTAINABILITY ISSUES}

ISSN 2345-0282 (online) http://jssidoi.org/jesi/ 2021 Volume 9 Number 2 (December) http://doi.org/10.9770/jesi.2021.9.2(18)

WIG-ESG is based on reports prepared by the independent provider of ESG research and ratings, Sustainalytics B.V., and on the Good Practices ranking based on statements made by companies with regard to application of corporate governance principles in their annual reports (Stock Exchange). Summing up the above considerations, it may be stated that the NFR_S index could form the eligibility basis for stock exchange indexes, while it cannot substitute the WIG-ESG index, due to, inter alia, other functions. The WIG-ESG index performs the basic functions of a typical stock exchange index, such as information or comparison functions. In turn, the NFR_S index disregards the stock market valuation of the companies and performs only the information function with regard to the level and scope of non-financial information disclosure.

\section{Results}

The non-financial reports analysis has shown a considerable diversity within the scope and manner of presenting social disclosures, which makes it difficult for stakeholders to compare them. The results presented below seem to confirm the formulated hypothesis. Both the differences in data presentation and the scope of information included in non-financial reports lead to the statement that comparability of corporate social disclosures requires a quantitative approach. Therefore, in accordance with the adopted methodology and research procedure presented in Table 6, each of the companies covered by the study and included in the WIG20 index was assessed via assigning an appropriate scoring method as per the adopted dichotomous scale (either " 0 " or " 1 ") which was then multiplied by the significance multiplier ("1", "1,5", "2"). The aggregate scores obtained by the studied companies are shown in Figure 1.

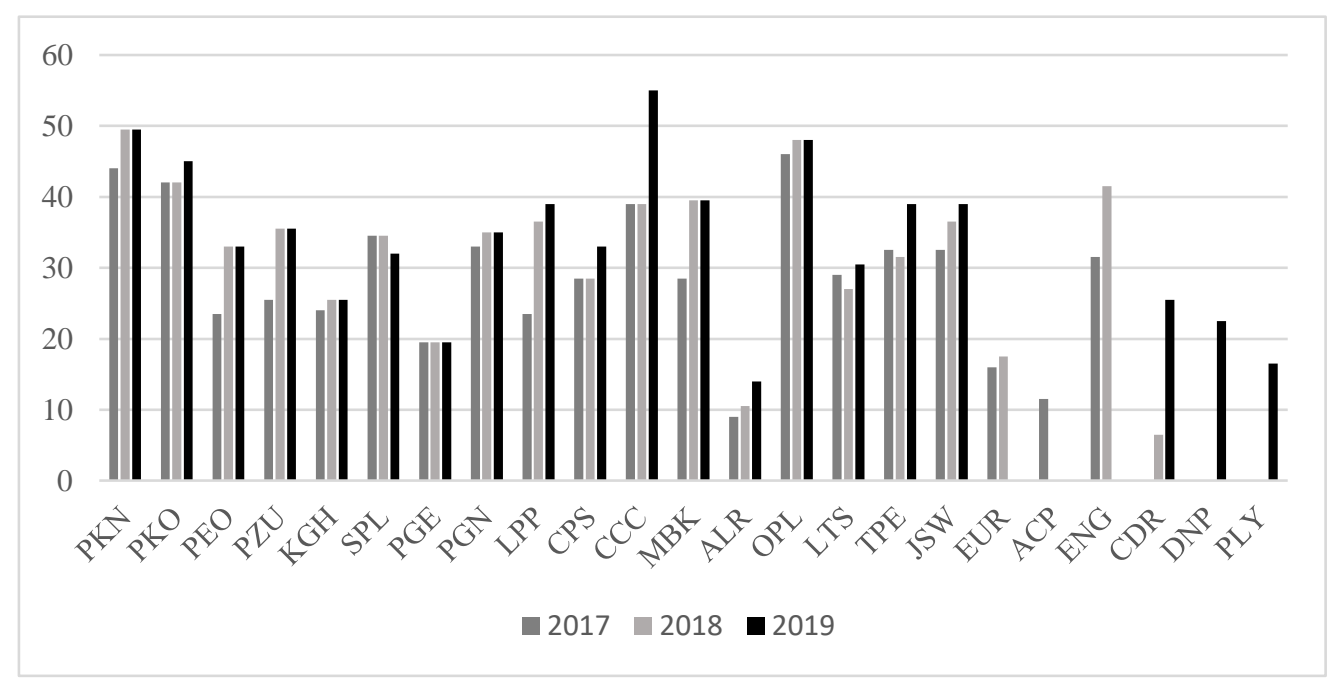

Figure 1. Results of social disclosures by company

Source: own study (x means that in the given year the company was not included in the WIG20 index).

It should be noted that none of the companies in any of the studied periods obtained more than $50 \%$ of the maximum possible score (110). The best score was attained by CCC in 2019: it was 55. There are at least several reasons explaining the relatively low scores obtained as a result of evaluation of the scope of published nonfinancial information. In the first place, the regulations on non-financial reporting have been in place for a short time. Moreover, despite the existing obligation, the scope of information to be published by companies has not been precisely specified. Consequently, it is up to the company to decide what kind and scope of information (and in which form) is to be published. It seems that there is a lack of appropriate incentives that would motivate companies to disclose non-financial information in a reliable and complex manner. However, the establishment of the WIG-ESG index by the Warsaw Stock Exchange may be considered to be a certain incentive inviting entities 


\section{ENTREPRENEURSHIP AND SUSTAINABILITY ISSUES}

ISSN 2345-0282 (online) http://jssidoi.org/jesi/ 2021 Volume 9 Number 2 (December) http://doi.org/10.9770/jesi.2021.9.2(18)

to increase the level of non-financial information disclosure. The WIG-ESG index provides its companies with a better ranking and improves its corporate image. Nevertheless, undoubtedly the transposition of Directive 2014/95/EU into the Polish legislation has increased the scope of corporate social disclosures, which is visible while comparing the disclosures for 2018 with those for 2017 (Figure 1). Certainly, there are still companies with no quantitative improvement or just little progress in the scope of disclosures. However, in the course of studying the non-financial reports, a qualitative improvement in 2018 (compared to 2017) was observed. Namely, the complexity and standard of the non-financial data presentation were higher, which is seen as an influence of CSRD. Hence, the scoring can be seen as a helpful method facilitating the comparability. However it is still limited due to the different scope of disclosers, since it not allowed to compare the quality. The scores obtained for the totality of the studied companies were analyzed using the basic metrics of descriptive statistics (Table 8). It is possible to notice the improved level of advancement in non-financial information disclosures in 2018, compared to 2017, which is confirmed by the position metrics such as the mean, median, quantile I and III. Year 2019 may be called the stabilization year, even though the increase in minimum value, increase in maximum value and increase in average scores obtained by the WIG20 companies may manifest a continuing rise in the advancement level. It should be noted that the drop in the minimum value in 2018 was due to the change in the WIG20 index composition [4]. The score of 7 was obtained by a company making its debut in the index. The drop in the median in 2019 can be explained on the same basis - two new companies were qualified to be included in the WIG20 index at that time.

Table 8. Descriptive statistics

\begin{tabular}{|c|c|c|c|}
\hline Basic distribution metrics & 2017 & 2018 & 2019 \\
\hline minimum value & 9 & 7 & 14 \\
\hline \multirow{2}{*}{$\begin{array}{r}\text { maximum value } \\
\text { mean }\end{array}$} & 46 & 50 & 55 \\
\hline & 29 & 32 & 34 \\
\hline & 29 & 35 & 34 \\
\hline Quantile I & 24 & 26 & 26 \\
\hline Quantile III & 34 & 39 & 39 \\
\hline
\end{tabular}

Source: own work.

The quantitative metrics of corporate social disclosures and applying the same metrics for each of the examined entities are prerequisites necessary to achieve comparability. The constructed tools in the form of the disclosure assessment scoring system (Figure 1 and Table 8) meet the proposal indicated in the above mentioned three theories that social disclosure should be treated as a manifesto of a company's accountability and the social value system. What is more, quantitative tools enable not only benchmarking, but also identification of leaders, i.e. the enterprises for which social corporate disclosure forms part of their corporate image. Therefore, the presented approach makes it possible to positively verify $\mathrm{H} 1$, but with above mentioned limits. The engagement of scoring method allows to state which information is revealed by company. But still does not allow to assess the quality of the disclosers. Hence still companies can be scored at the same level, even the scope of revealed information differs on multiple levels. Lack of universal quantitative tools makes it impossible to objectively compare the scopes of non-financial information publications. Nevertheless quantitative tools such as the rating or below presented index allow comparability and create added value to stakeholders.

As a result of the comparative analysis, it is possible to state that the scores obtained by the individual companies (Figure 1) and the descriptive statistics metrics for the totality of the companies have shown an insufficient scope of social disclosures. Since the WIG20 index presents the top twenty of the biggest and strongest companies which are seen as the market benchmark in many areas, the highest possible score would be expected. Even though in individual cases some improvements can be observed, the scope is still low, and the maximum score for 


\section{ENTREPRENEURSHIP AND SUSTAINABILITY ISSUES}

ISSN 2345-0282 (online) http://jssidoi.org/jesi/ 2021 Volume 9 Number 2 (December) http://doi.org/10.9770/jesi.2021.9.2(18)

social disclosures did not exceed $50 \%$ of the maximum value. Lack of incentives for publishing non-financial information is also noticeable among experts: the new directive draft proposed by the European Commission focuses on imposing an obligation on enterprises to provide qualitative and quantitative information. Despite the indicated differences in disclosing non-financial information across the individual countries, it seems that stakeholders' expectations are higher, therefore subsequent regulative measures are being taken.

The next stage of the empirical study was rating the individual companies on the basis of their scores. The rating shows their advancement level in terms of corporate social disclosures. Based on the score obtained by a given company in a given year, the companies were classified on a 5-grade scale from $\mathrm{A}+$ to $\mathrm{E}$, where $\mathrm{A}+$ means the highest scope of corporate social disclosure, and E the lowest, pursuant to the methodology presented in Table 7. The highest rating assigned to the studied companies was B, which meant disclosing from 40 to $55 \%$ defined nonfinancial metrics. Both in 2017 and in 2018, the B rating was obtained by two companies, whereas in 2019 the number of B-rated companies doubled. The most numerous rating group was C (10 companies in 2017, 12 in 2018 and 10 in 2019). On average 2-3 companies obtained the lowest rating over the years. These most often were the companies making their debut in the WIG20 index, which for the first time had to tackle reporting of extended non-financial information. It is worth noting that none of the companies was able to achieve the highest ratings: $\mathrm{A}+, \mathrm{A}$ or $\mathrm{B}+$, which may be due to the relatively short experience of Polish companies in non-financial reporting and the insufficiently detailed legal regulations in that regard. Figure 2 shows the aggregate numbers of companies in individual rating groups with regard to $\mathrm{S}$ category non-financial reporting.

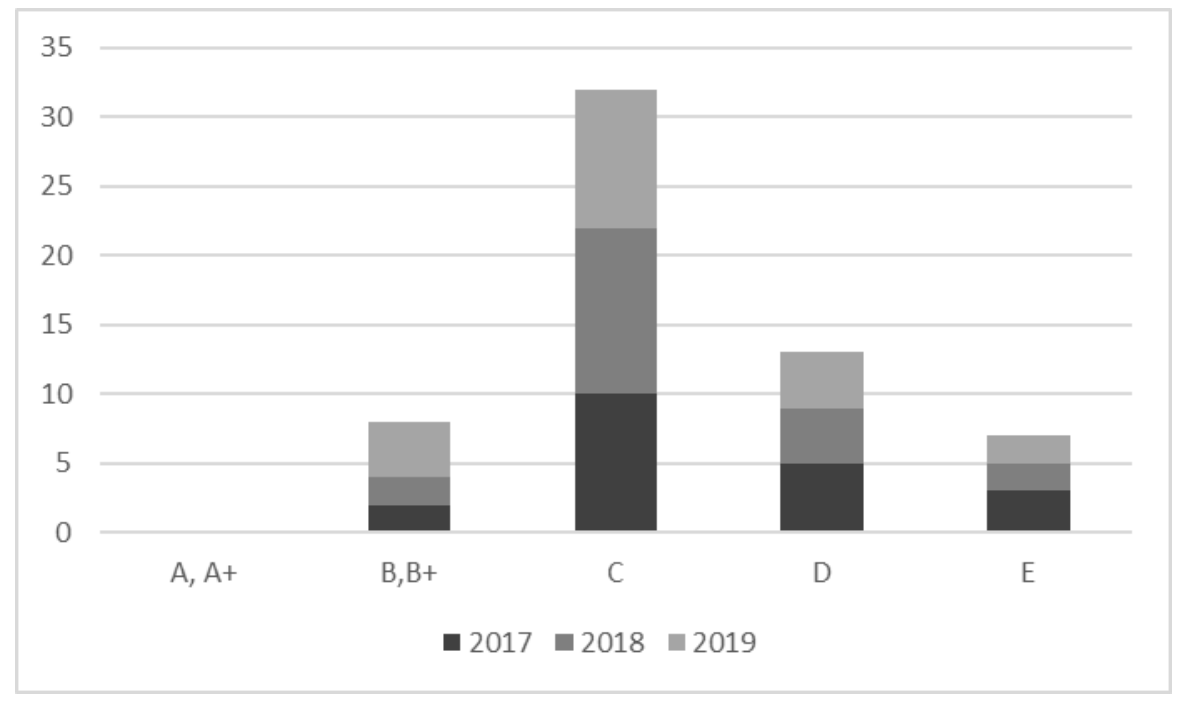

Figure 2. Benchmarking of corporate social disclosure - aggregated

Source: own work.

The analysis of the comparability of corporate social disclosure reporting led to the following conclusions: only two companies, i.e. PKN Orlen and Orange, having attained the B rating, managed to keep it throughout the study period. As many as seven companies improved their ratings in the analyzed period, increasing the scope of disclosures in the reports. These were: PKO BP, PEKAO, PZU, LPP, CCC, Eurocash, CD Projekt. The lowest rating (E) was obtained by Alior and Dino Polska. Table 9 shows detailed data about the ratings achieved by the individual companies. The ratings assigned to the companies (Figure 2, Table 9) on the basis of the scores obtained by them (Figure 1) confirm the conclusion that the companies covered by the study showed insufficient social disclosure levels. Benchmarking has demonstrated the prevalence of $\mathrm{C}$ and $\mathrm{D}$ ratings. The year-to-year improvement is visible mostly in 2018, while in 2019 there are only a few cases, which means that the legal regulations that entered into force in 2017 were sufficient to improve the scope of corporate social disclosures, but it was a one-off event. Hence, there is a need to create incentives that will keep the growing trend of improving 
the non-financial reporting, and a rating or index with an objective and quantitative base can be used to encourage companies to take a challenge and show better social disclosure performance. The benchmarking results (Table 9) as well support the $\mathrm{H} 2$ and indicate that there is a need to imply quantitative measures to ensure comparability and thus help stakeholders compare social performance.

Table 9. Benchmarking of corporate social disclosures - individual

\begin{tabular}{|l|c|c|c|}
\hline Company & 2017 & 2018 & 2019 \\
\hline PKN & B & B & B \\
\hline PKO & C & C & B \\
\hline PEO & D & C & C \\
\hline PZU & D & C & C \\
\hline KGH & D & D & D \\
\hline SPL & C & C & C \\
\hline PGE & D & D & D \\
\hline PGN & C & C & C \\
\hline LPP & D & C & C \\
\hline CPS & C & C & C \\
\hline CCC & C & C & B \\
\hline MBK & C & C & C \\
\hline ALR & E & E & E \\
\hline OPL & B & B & B \\
\hline LTS & C & C & C \\
\hline TPE & C & C & C \\
\hline JSW & C & C & C \\
\hline EUR & E & D & X \\
\hline ACP & E & X & X \\
\hline ENG & C & C & X \\
\hline CDR & X & E & D \\
\hline DNP & X & X & E \\
\hline PLY & X & X & D \\
\hline
\end{tabular}

As it was indicated, due to difficulties in assessing social disclosures in sustainability reporting there is a need to select quantitative measures to help stakeholders to compare social performance. The authorial NFR_S index is a tool that complements the considerations regarding social disclosures in non-financial reporting, and supports verification of the hypotheses. The NFR_S index is used for comparing over time the advancement level of nonfinancial reporting in S category for all the companies included in the WIG20 index. It is a sum of scores which the ith company obtained for the non-financial metrics disclosed in the report $\left(n_{i}\right)$ and the weight of the ith company in the WIG20 index $\left(w_{i}\right)$. Its value may range from 0 to 110. The higher the index value, the higher the scope of corporate social disclosure. The values of the NFR_S index for the whole WIG20 are shown in Figure 3. 


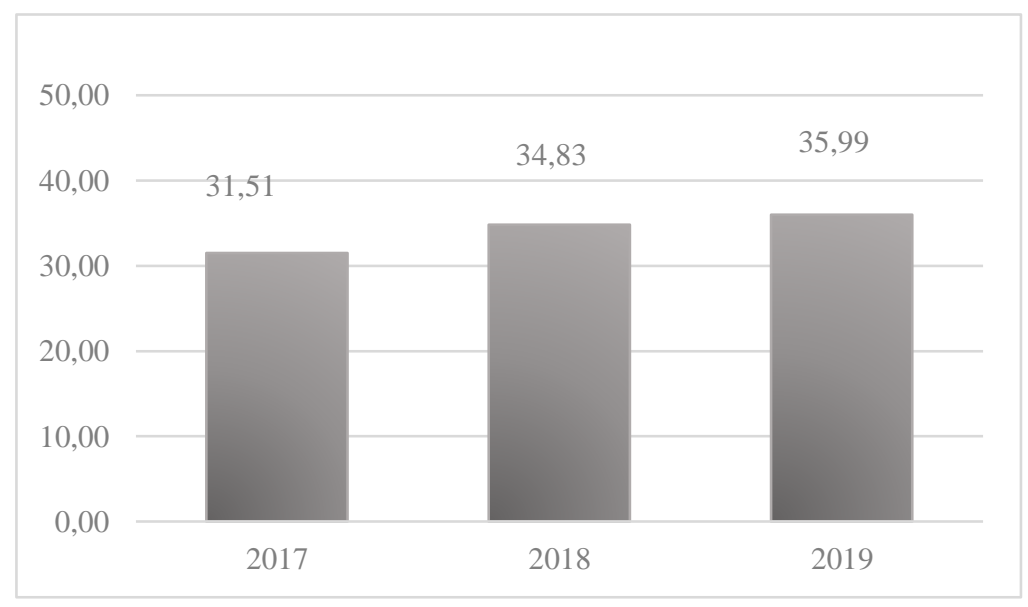

Figure 3. NFR_S index values

Source: own work.

In 2017, the NFR_S value amounted to 31.51 points, whereas in 2019 it rose to 35.99. A comparative analysis of the index value makes it possible to draw a conclusion that the scope of corporate social disclosure in the WIG20 index companies has improved. The NFR_S index value has been rising, nevertheless it seems that a significant increase in disclosures cannot be expected without appropriate incentives or changes in the legal regulations.

\section{Discussion}

An important contribution to the research on social disclosures in non-financial reporting is the proposal to compare the content of the individual reports pursuant to uniform (standardized) principles. Application of a dichotomous scale ("0" no disclosure, "1" disclosure) in scoring method to assess corporate social disclosures, followed by presenting the results of the assessment in the form of benchmarking and an index allow for comparisons in the area of corporate social disclosures. A similar approach to assessment of corporate social disclosures was also taken by Singhania and Gandhi (2015) and Skouloudis et al. (2010). In the latter case, however, scoring from 0 to 4 points was used. Drawing up standardized assessment procedures for corporate social disclosures enables achieving comparability via changing the narrative character of social disclosures, as indicated by Choudhury (Choudhury, 2016). Therefore, the study results may support stakeholders in comparing social performance and thus help them in business decisions, especially as such information is of major significance also in making investment decisions (Ernst and Young, 2017). The devised index, in turn, enables assessment of aggregated corporate social disclosures and constitutes a universal tool which may be applied in further studies.

The quantitative tools developed in order to assess corporate social disclosures described in this paper seem to be the answer to the needs of stakeholders who expected structured (La Torre et al., 2018), reliable (La Torre, 2020) and comparable non-financial information (Carungu et al., 2020). The authors proposed some tools that enable the comparability of social disclosers. The measures surly can be imply by stakeholders in comparing social performance. But still these measures are limited and there is the scape to develop more sophisticated tools/methods, where the quality of disclosures will be the issue.

Our article makes several contributions to the existing theory and research. Firstly, the conducted empirical study corresponds to the legislative changes proposed by the European Commission and the IFRS Foundation, as it focuses on improving the comparability of disclosures in sustainability reporting, including social disclosures. 


\section{ENTREPRENEURSHIP AND SUSTAINABILITY ISSUES}

ISSN 2345-0282 (online) http://jssidoi.org/jesi/ 2021 Volume 9 Number 2 (December)

http://doi.org/10.9770/jesi.2021.9.2(18)

Moreover, our research findings have confirmed the basic dysfunctions of the current reporting system, i.e. complexity, low reliability and limited comparability (in terms of time and space) of social disclosures. Also, the research results point to the need to introduce legislative changes. Secondly, our research fitted into the growing trend of research on corporate social disclosure and its comparability (see Table 1) and allowed us to find a justification for the theoretical assumptions of social disclosures in reporting. Despite the late development of CSR in Poland in relation to the West, as well as many cultural and economic limitations, Polish enterprises covered by the research study present a fairly high and growing interest in social disclosures. A social disclosure can be interpreted as a way to meet the expectations of stakeholders and as well as to legitimize corporate activities. It can also be read as an internal need of companies to show the represented system of social values. The scope of social disclosures is systematically growing, nevertheless the pace of changes depends on several institutional conditions that should be considered in the perspective of industry or benchmarking partners, which may strengthen the comparability of research results.

Our research approach extends the perspective of disclosure analysis presented so far in the literature on the subject. The research studies completed so far in that regard pertained mainly to publicly listed companies and focus on interdependencies between the scale of disclosures and liquidity, indebtedness, and profitability of the listed companies (Xiaowen, 2012) and on the relations between the scale of disclosures and the cost of equity (de Souza Gonçalves et al., 2014). Like us, de Souza Gonçalves et al. applied the desk research method to analyze non-financial reports. Further, to evaluate the level of social disclosure of public companies in Brazil, they used an index of 13 indicators. However, this demonstration was based on an indicator that only evaluated social disclosure relating to external social programs, hence the analyzed scope of disclosure was narrower. Similarly to our research, they engaged benchmarking to enable the comparability of corporate social disclosures by classifying the information by level, from "restricted" (lowest level of information) to "low", "medium" or "high" (de Souza Gonçalves et al., 2014).

In addition to achieving comparability of corporate social disclosures, the outcome of this paper is the NFR_S index that enables aggregated assessment of disclosures. A similar task was tackled by, inter alia, Singhania and Gandhi (Singhania and Gandhi, 2015). They constructed the social and environmental disclosure index for Indian companies in order to examine the relationship between corporate social disclosures and selected corporate attributes. Similarly as in our case, their study covered listed companies, however, the index they applied in the assessment was unweighted, but similarly as in our research, a disclosure index approach was used to measure the extent of disclosure of social and environmental information. Singhania and Gandhi, likewise de Souza Gonçalves et al., 2014, Skouloudis et al., 2010, in the course of assessing corporate social disclosures focused on several kinds of disclosures, whereas our article applied as many as 76 metrics recommended by GRI. Due to that, application of the NFR_S index in business practice may bring a number of benefits in both macro and micro terms, because the index structure enables comparisons of corporate social disclosures for any group/ sector of listed companies, at any time and place (comparability in terms of time and space). Moreover, the devised index may also be applied in further studies, e.g. studying the relationship between corporate social disclosures and company characteristics such as sector of operations, size, and financial performance. In turn, from the point of view of a single enterprise, (on the micro scale) a high value of the NFR_S index provides a possibility of improving the company public relations and enhancing the company image as a partner for social activities (it contributes to development of social capital). In case the index value is low compared to competitors, this could be an incentive for the company to introduce changes and improve its social attitude. 


\section{ENTREPRENEURSHIP AND SUSTAINABILITY ISSUES}

ISSN 2345-0282 (online) http://jssidoi.org/jesi/

2021 Volume 9 Number 2 (December)

http://doi.org/10.9770/jesi.2021.9.2(18)

\section{Conclusions}

Corporate social disclosure is one of the three pillars of sustainability reporting. However, due to the complexity and multidimensionality of this category, both the number and kind of disclosures applied by companies are varied. This was confirmed by the study described in this article, where by means of a standardized procedure a rating and an authorial index were developed. This made it possible to attain the goal, i.e. achieving comparability of corporate social disclosures among Polish listed companies.

Comparability of corporate social disclosures reveals gaps in the disclosing practices of publicly listed companies included in the WIG20 index. Hence there is much room for improvement, which could be significant from stakeholders' point of view. This was confirmed by both individual ratings of the particular companies, the data analysis for the totality of companies, and the NFR_S index values for the three subsequent business years. It appears that this state of affairs is attributable to several reasons. Firstly, Polish companies' experience in obligatory reporting of extended non-financial information is rather small, dating back to as late as 2017 . Secondly, the scope of non-financial disclosures imposed by the accounting regulation is limited to a description of policies, results and risks identified by the entity with regard to social and labor issues, natural environment protection, human rights observance, and corruption counteracting. In this context, the Polish legal framework requires legislative changes to clarify the scope of non-financial disclosures and/or to develop a catalogue of recommended metrics. Finally, to achieve a higher level of non-financial reporting in Poland, it is necessary for companies not only to increase the number of presented metrics, but also to improve their quality. The narrative, declarative character of non-financial reports should be verified by external attestation bodies. In this context, it is worth underlining some practical implications resulting from the research study described herein. That is, the rating of the WIG20 companies and the NFR_S index values may become an important factor for investors in decision-making as well as for Polish legislative bodies in the law-making process.

However, drawing conclusions on the basis of the conducted empirical studies may be subject to certain limitations. Firstly, the research via the Delphi method was conducted on a small research sample, and the experts may be subjectively biased. Secondly, the sample size could be increased by considering more companies, or a sectoral approach might be used. Nevertheless, regardless of the identified limitations, this paper furnishes the ground for further research on a much broader scale (analyzing the NFR_S index over the subsequent years) and also in other areas of non-financial reporting (drawing up the NFR_G and NFR_E indexes).

\section{References}

de Abreu, M. C. S., de Castro, F., de Assis Soares, F. and da Silva Filho, J. C. L. (2012), "A comparative understanding of corporate social responsibility of textile firms in Brazil and China", Journal of Cleaner Production, Vol. 20 No. 1, pp. 119-126, doi: 10.1016/j.jclepro.2011.08.010.

Ali, W., Frynas, J. G. and Mahmood, Z. (2017), "Determinants of corporate social responsibility (CSR) disclosure in developed and developing countries: A literature review”, Corporate Social Responsibility and Environmental Management, Vol. 24 No. 4, pp. 273-294, doi:10.4467/24498939IJCM.18.011.8390.

Ali, I., Lodhia, S. and Narayan, A. K. (2020), "Value creation attempts via photographs in sustainability reporting: a legitimacy theory perspective", Meditari Accountancy Research, doi: 10.1108/medar-02-2020-0722.

Biondi, L., Dumay, J. and Monciardini, D. (2020), "Using the International Integrated Reporting Framework to comply with EU Directive 2014/95/EU: can we afford another reporting façade?", Meditari Accountancy Research, Vol. 28 No. 5, pp. 889-914, doi: 10.1108/MEDAR-01-2020-0695. 


\section{ENTREPRENEURSHIP AND SUSTAINABILITY ISSUES}

ISSN 2345-0282 (online) http://jssidoi.org/jesi/

2021 Volume 9 Number 2 (December)

http://doi.org/10.9770/jesi.2021.9.2(18)

Boiral, O. (2013), "Sustainability reports as simulacra? A counter-account of A and A+ GRI reports, Accounting", Auditing \& Accountability Journal, Vol. 26 No. 7, pp. 1036-1071, doi: 10.1108/AAAJ-04-2012-00998.

Campbell, J. L. (2007), "Why would corporations behave in socially responsible ways? An institutional theory of corporate social responsibility", Academy of Management Review, Vol. 32 No. 3, pp. 946-967, doi: 10.5465/amr.2007.25275684.

Carungu, J., Di Pietra, R. and Molinari, M. (2020), "Mandatory vs voluntary exercise on non-financial reporting: does a normative/coercive isomorphism facilitate an increase in quality?", Meditari Accountancy Research, doi: 10.1108/MEDAR-08-2019-0540.

Chen, J. C., and Roberts, R. W. (2010), "Toward a more coherent understanding of the organization-society relationship: A theoretical consideration for social and environmental accounting research", Journal of Business Ethics, Vol. 97 No. 4, pp. 651-665, doi:10.1007/s10551-010-0531-0.

Choudhury, B. (2016), "Social disclosure”, Berkeley Business Law Journal, Vol. 13 No. 1, pp. 183-218.

Consultation Paper on Sustainability Reporting (2020), IFRS Foundation.

Czaja-Cieszyńska H. (2018), "Non-financial reporting as a challenge for the contemporary accounting system", European Journal of Service Management, Vol. 27 No. 1, pp. 31-37, doi: 10.18276/ejsm.2018.27/1-04.

Czaja-Cieszyńska, H. and Kochański, K. (2019), "Sustainable development reporting of selected socially responsible listed companies", Zeszyty Naukowe Akademii Morskiej w Szczecinie, Vol. 60 No. 132, pp. 93-100, doi: 10.17402/376.

SDD (2021), „Sustainability Disclosure Database - GRI”, available at: http://database.globalreporting.org (accessed 30 April 2021).

Deegan, C. (2002), "Introduction: The legitimising effect of social and environmental disclosures - A theoretical foundation", Accounting, Auditing \& Accountability Journal, Vol. 15 No. 3, pp. 282-311, doi: 10.1108/09513570210435852.

Di Tullio, P., Valentinetti, D., Nielsen, C. and Rea, M. A. (2019), "In search of legitimacy: a semiotic analysis of business model disclosure practices”, Meditari Accountancy Research, Vol. 28 No.5, pp. 863-887, doi: 10.1108/MEDAR-02-2019-0449

Donaldson, T. and Preston, L. E. (1995), "The stakeholder theory of the corporation: Concepts, evidence, and implications", Academy of management Review, Vol. 20 No. 1, pp. 65-91, doi: 10.2307/258887.

Doni, F., Bianchi Martini, S., Corvino, A. and Mazzoni, M. (2020), "Voluntary versus mandatory non-financial disclosure: EU Directive 95/2014 and sustainability reporting practices based on empirical evidence from Italy", Meditari Accountancy Research, Vol. 28 No. 5 , pp. 781-802, doi: 10.1108/MEDAR-12-2018-0423.

Directive 2014/95/EU of the European Parliament and of the Council of 22 October 2014 Amending Directive 2013/34/EU as Regards Disclosure of Non-Financial and Diversity Information by Certain Large Undertakings and Groups; EU law: Brussels, Belgium, 2014.

Eccles, R. G., Ioannou, I. and Serafeim, G. (2014), "The impact of corporate sustainability on organizational processes and performance”, Management Science, Vol. 60 No. 11, pp. 2835-2857, doi: 10.2139/ssrn.1964011

Ernst and Young (2017), "Is Your Non-Financial Performance Revealing the True Value of Your Business to Investors? Tomorrow's Investment Rules 2017”, available at: https://www.ey.com/en_gl/assurance/is-your-nonfinancial-performance-revealing-the-true-value-ofyour-business (accessed on 19 April 2021).

García-Sánchez, I. M., Rodríguez-Ariza, L. and Frías-Aceituno, J. V. (2013), "The cultural system and integrated reporting”, International business review, Vol. 22 No. 5, pp. 828-838, doi: 10.1016/j.ibusrev.2013.01.007.

Farneti, F., Casonato, F., Montecalvo, M. and de Villiers, C. (2019), "The influence of integrated reporting and stakeholder information needs on the disclosure of social information in a stateowned enterprise”, Meditari Accountancy Research, Vol. 27 No. 4, pp. 556-579, doi: 10.1108/MEDAR-01-2019-0436.

Fernando, S. and Lawrence, S. (2014), "A theoretical framework for CSR practices: Integrating legitimacy theory, stakeholder theory and institutional theory”, Journal of Theoretical Accounting Research, Vol. 10 No. 1, pp. 149-178.

Fijałkowska, J., Zyznarska-Dworczak, B. and Garsztka, P. (2018), "Corporate social-environmental performance versus financial performance of banks in Central and Eastern European countries”, Sustainability, Vol. 10 No. 3, pp. 1-22, doi: 10.3390/su10030772. 


\section{ENTREPRENEURSHIP AND SUSTAINABILITY ISSUES}

ISSN 2345-0282 (online) http://jssidoi.org/jesi/ 2021 Volume 9 Number 2 (December) http://doi.org/10.9770/jesi.2021.9.2(18)

Fifka, M. S. (2013), "Corporate responsibility reporting and its determinants in comparative perspective-a review of the empirical literature and a meta-analysis”, Business Strategy and the Environment, Vol. 22 No. 1, pp. 1-35, doi: doi:10.1002/bse.729.

Freeman, R. E. and Reed, D. L. (1983), "Stockholders and stakeholders: A new perspective on corporate governance", California management review, Vol. 25 No. 3, pp. 88-106, doi: 10.2307/41165018.

GPW (2021), Giełda Papierów Wartościowych w Polsce, available at: www.gpw.pl (accessed on 12 March 2021).

GSSB (2016), Consolidated Set of GRI Sustainability Reporting Standards, available at: https://www.globalreporting.org (accessed on 12 March 2021).

Hąbek, P., \& Wolniak, R. (2016). Assessing the quality of corporate social responsibility reports: the case of reporting practices in selected European Union member states. Quality \& quantity, 50(1), 399-420.

Hazelton, J. and Perkiss, S. (2018), How useful are CSR reports for investors? The problems of comparing environmental and social disclosures, in Boubaker, S., Cumming, D. and Nguyen, D. (Eds.), Research Handbook of Finance and Sustainability, Edward Elgar Publishing, UK, pp. 93-109.

Jackson, G., Bartosch, J., Avetisyan, E., Kinderman, D. and Knudsen, J. S. (2020), "Mandatory non-financial disclosure and its influence on CSR: An international comparison", Journal of Business Ethics, Vol. 162 No. 2, pp. 323-342, doi: 10.1007/s10551-019-04200-0.

Krasodomska, J. (2015). CSR disclosures in the banking industry. Empirical evidence from Poland. Social Responsibility Journal, 11(3), 406-423. https://doi.org/10.1108/SRJ-02-2013-0019

Krasodomska, J., Michalak, J. and Świetla, K. (2020), “Directive 2014/95/EU: Accountants' understanding and attitude towards mandatory non-financial disclosures in corporate reporting”, Meditari Accountancy Research, Vol. 28 No. 5, pp. 751-779, doi: 10.1108/MEDAR-062019-0504.

Krasodomska, J. and Zarzycka, E. (2020), "Key performance indicators disclosure in the context of the EU directive: when does stakeholder pressure matter?", Meditari Accountancy Research, Vol. 29 No. 7, pp. 1-30, doi: 10.1108/MEDAR-05-2020-0876.

Kamal, Y. (2021), "Stakeholders expectations for CSR-related corporate governance disclosure: evidence from a developing country", Asian Review of Accounting, Vol. 29 No. 2, pp. 97-127, doi: 10.1108/ARA-04-2020-0052.

Kaur, A. and Lodhia, S. (2018), "Stakeholder engagement in sustainability accounting and reporting", Accounting, Auditing \& Accountability Journal, Vol. 31 No. 1, pp. 338-368, doi:10.1108/aaaj-12-2014-1901.

La Torre, M., Sabelfeld, S., Blomkvist, M. and Dumay, J. (2020), "Rebuilding trust: sustainability and non-financial reporting and the European Union regulation”, Meditari Accountancy Research, Vol. 28 No. 5, pp. 701-725, doi: 10.1108/MEDAR-06-2020-0914.

La Torre, M., Sabelfeld, S., Blomkvist, M., Tarquinio, L. and Dumay, J. (2018), "Harmonising nonfinancial reporting regulation in Europe: practical forces and projections for future research", Meditari Accountancy Research, Vol. 26 No. 4, pp. 598-562, doi: 10.1108/MEDAR02-2018-0290.

Lombardi, R. and Secundo, G. (2020), "The digital transformation of corporate reporting - a systematic literature review and avenues for future research", Meditari Accountancy Research, doi: 10.1108/MEDAR-04-2020-0870.

De Luca, F. (2020), "Prelims", Mandatory and Discretional Non-financial Disclosure After the European Directive 2014/95/EU, Emerald Publishing Limited, Bingley, pp. i-xvi. doi: 10.1108/978-1-83982-504-020201001.

Mahoney, L. S., Thorne, L., Cecil, L. and LaGore, W. (2013), "A research note on standalone corporate social responsibility reports: Signaling or greenwashing?”, Critical perspectives on Accounting, Vol. 24 No. 4-5, pp. 350-359, doi: 10.1016/j.cpa.2012.09.008.

Martínez-Ferrero, J., Ruiz-Cano, D. and García-Sánchez, I. M. (2016), "The causal link between sustainable disclosure and information asymmetry: The moderating role of the stakeholder protection context", Corporate Social Responsibility and Environmental Management, Vol. 23 No. 5, pp. 319-332, doi: 10.1002/csr.1379.

Michelon, G., Pilonato, S. and Ricceri, F. (2015), "CSR reporting practices and the quality of disclosure: An empirical analysis”, Critical perspectives on accounting, Vol. 33(C), pp. 59-78, doi: 10.1016/j.cpa.2014.10.003. 


\section{ENTREPRENEURSHIP AND SUSTAINABILITY ISSUES}

ISSN 2345-0282 (online) http://jssidoi.org/jesi/ 2021 Volume 9 Number 2 (December)

http://doi.org/10.9770/jesi.2021.9.2(18)

Nicolo, G., Zanellato, G. and Tiron-Tudor, A. (2020), "Integrated reporting and European state-owned enterprises: A disclosure analysis pre and post 2014/95/EU”, Sustainability, Vol. 12 No. 5, 1908, doi: 10.3390/su12051908.

O'Dwyer, B. (2001), “The legitimacy of accountants' participation in social and ethical accounting, auditing and reporting”, Business Ethics: A European Review, Vol. 10 No. 1, pp. 27-39, doi:10.1111/1467-8608.00209.

Orij, R. (2010), "Corporate social disclosures in the context of national cultures and stakeholder theory", Accounting, Auditing \& Accountability Journal, Vol. 23 No. 7, pp. 868-889, doi: 10.1108/09513571011080162.

Patten, D.M. (1991), "Exposure, legitimacy and social disclosure", Journal of Accounting and Public Policy, Vol. 10 No. 4, pp. 297-308, doi: 10.1016/0278-4254(91)90003-3.

Pedersen, E. R. G., Neergaard, P., Pedersen, J. T. and Gwozdz, W. (2013), "Conformance and deviance: Company responses to institutional pressures for corporate social responsibility reporting”, Business Strategy and the Environment, Vol. 22 No. 6, pp. 357-373, doi: 10.1002/bse.1743.

Singhania, M. and Gandhi, G. (2015), "Social and environmental disclosure index: perspectives from Indian corporate sector", Journal of Advances in Management Research, Vol. 12 No. 2, pp. 192-208, doi: 10.1108/JAMR-12-2013-0069.

Skouloudis, A., Evangelinos, K. and Kourmousis, F. (2010), “Assessing non-financial reports according to the Global Reporting Initiative guidelines: evidence from Greece”, Journal of Cleaner Production, Vol. 18 No. 5, pp. 426-438, doi: 10.1016/j.jclepro.2009.11.015.

de Souza Gonçalves, R., de Medeiros, O. R., Weffort, E. F. J. and Niyama, J. K. (2014), “A social disclosure index for assessing social programs in Brazilian listed firms", Accounting in Latin America (Research in Accounting in Emerging Economies), Vol. 14, Emerald Group Publishing Limited, Bingley, pp. 75-103, doi:10.1108/S1479-356320140000014002.

Szadziewska, A., Spigarska, E. and Majerowska, E. (2018), "The disclosure of non-financial information by stock-exchange-listed companies in Poland, in the light of the changes introduced by the Directive 2014/95/EU, Zeszyty Teoretyczne Rachunkowości, Vol. 99 No. 155, pp. 65-95, doi: 10.5604/01.3001.0012.2933.

Widiarto Sutantoputra, A. (2009), "Social disclosure rating system for assessing firms' CSR reports", Corporate Communications: An International Journal, Vol. 14 No. 1, pp. 34-48, doi: 10.1108/13563280910931063.

Wirth, H., Kulczycka, J., Hausner, J., \& Koński, M. (2016). Corporate Social Responsibility: Communication about social and environmental disclosure by large and small copper mining companies. Resources Policy, 49, 53-60.

Van der Laan Smith, J., Adhikari, A. and Tondkar, R. H. (2005), "Exploring differences in social disclosures internationally: A stakeholder perspective”, Journal of Accounting and Public Policy, Vol. 24 No. 2, pp. 123-151, doi: 10.1016/j.jaccpubpol.2004.12.007.

Venturelli, A., Caputo, F., Leopizzi, R. and Pizzi, S. (2019), "The state of art of corporate social disclosure before the introduction of nonfinancial reporting directive: A cross country analysis. Social Responsibility Journal, Vol. 15 No. 4, pp. 409-423, doi: 10.1108/SRJ-122017-0275.

Xiaowen S., (2012), "Corporate Characteristics and Internal Control Information Disclosure- Evidence from Annual Reports in 2009 of Listed Companies in Shenzhen Stock Exchange”, Physics Procedia, Vol. 25, pp. 630-635, doi: 10.1016/j.phpro.2012.03.136.

Zyznarska-Dworczak, B. (2018a), "The development perspectives of sustainable management accounting in central and Eastern European countries”, Sustainability, Vol. 10 No. 5, pp. 1-21, doi: 10.3390/su10051445.

Zyznarska-Dworczak, B. (2018b), "Legitimacy theory in management accounting research", Problemy Zarzadzania, Vol. 16 No.1 (72), pp. 195-203, doi: 10.7172/1644-9584.72.12.

Zyznarska-Dworczak, B. (2020), "Sustainability Accounting-Cognitive and Conceptual Approach”, Sustainability, Vol. 12 No. 23, 9936, doi: 10.3390/su12239936. 


\section{ENTREPRENEURSHIP AND SUSTAINABILITY ISSUES}

ISSN 2345-0282 (online) http://jssidoi.org/jesi/

2021 Volume 9 Number 2 (December)

http://doi.org/10.9770/jesi.2021.9.2(18)

\section{Acknowledgements}

The project is financed within the framework of the program of the Minister of Science and Higher Education under the name "Regional Excellence Initiative" in the years 2019 - 2022; project number 001/RID/2018/19; the amount of financing PLN 10,684,000.00. The paper is also partially financed from the research funds of the Department of Accounting and Financial Audit, Poznań University of Economics and Business.

Author Contributions: All authors contributed to the research presented in this paper and to the preparation of the final manuscript.

Beata ZYZNARSKA-DWORCZAK, PhD habil., Associate professor at Poznan University of Economics and Business, currently works at the Department of Accounting and Financial Audit. A certified auditor - a member of Polish Chamber of Statutory Auditors, an ordinary member of the Polish Association of Accountants and also a member of the Polish Economic Society. Her current academic interests are: non-financial disclosures in corporate reporting, sustainability accounting and sustainability assurance.

ORCID ID: 0000-0002-0827-2583

Hanna CZAJA-CIESZYŃSKA, PhD, Adjunct at the Institute of Economics, Department of Accounting University of Szczecin. Her research areas: accounting of small and medium-sized enterprises, non-financial reporting, corporate social responsibility, sustainable development reports, NGO accounting.

ORCID ID: 0000-0002-6425-9519

Dominika KORDELA, PhD, Adjunct at the Institute of Economics, Department of Sustainable Finance and Capital Markets University of Szczecin. Main research areas: alternative finance, finance of small and medium companies, financial markets for small and medium companies, financial innovation.

ORCID ID: 0000-0002-4826-1352

Make your research more visible, join the Twitter account of ENTREPRENEURSHIP AND SUSTAINABILITY ISSUES: @Entrepr69728810

Copyright (C) 2021 by author(s) and VsI Entrepreneurship and Sustainability Center

This work is licensed under the Creative Commons Attribution International License (CC BY).

http://creativecommons.org/licenses/by/4.0/

C. (i) Open Access 